\title{
Role of CPPU and Application Stages with Other PGR's on Bunch and Berry Characters in New Grape cv. Italia under Tamil Nadu Conditions
}

\author{
S. Senthilkumar ${ }^{1,2^{*}}$, R.M. Vijayakumar ${ }^{1}$, K. Soorianathasundaram ${ }^{1}$ and D. Durga Devi ${ }^{1}$ \\ ${ }^{1}$ Department of Fruit Crops, Tamil Nadu Agricultural University, Coimbatore-641 003, India \\ ${ }^{2}$ School of Agriculture, LPU, Punjab - 144411, India \\ *Corresponding author
}

\section{A B S T R A C T}

An investigation was performed to study the impact of CPPU (alone and in

Keywords

Grape, Italia,

Bioregulators,

CPPU, Bunch and

berry character

Article Info

Accepted:

04 March 2018

Available Online:

10 April 2018 combination with other PGR's) and their application stage on berry development, yield and quality in grape (Vitis vinifera L.) cv. Italia at Horticultural College and Research Institute, TNAU, Coimbatore. Treatments were imposed over the vines pruned to standardized pruning level of pruning $50 \%$ of canes for crop yield and $50 \%$ of canes for vegetative growth and observed for impact on bunch and berry characters. The results revealed that bunches sprayed with CPPU (1 ppm) recorded the maximum berry width at pea stage of $7-8 \mathrm{~mm}$ berry size. The maximum peel weight, peel thickness and pedicel thickness was registered with CPPU (1 ppm) imposed both at 2-3 $\mathrm{mm}$ and at $7-8 \mathrm{~mm}$ berry size stage. But, the results on yield related traits found to be positive with the bunch sprays of $\mathrm{GA}_{3}(10 \mathrm{ppm})+$ Brassinosteroid $(1 \mathrm{ppm})$ at 7-8 $\mathrm{mm}$ berry size.

\section{Introduction}

Grape is an excellent fruit crop which found to indulge tremendous usage with them and is so unique that no fruit can challenge their superiority. It found to have a good scope for wider cultivation in all the temperate regions and has been grown more recently in tropical and subtropical climates. There are more than 1000 grape cultivars known all over the world but only a limited number are commercially cultivated. In India, prevalence with wider range of soil and climatic conditions maximized its vitality for better productivity, especially the climatic conditions in Tamil $\mathrm{Nadu}$ is unique and favours production in large scale throughout the year. The area under grape cultivation in the last three decades increasing steadily with the introduction of exotic varieties. In that line, an exotic grape cultivar, Italia, introduced from University of California, USA grained greater importance.

Plant bioregulators have gained greater significance in regulating several fruit 
development activities like chemical thinning, increasing fruit set and size, enhancing colouration and enhancing or delaying ripening of fruits (Winkler et al., 1974). Both intensive and extensive application has bought enhanced production and betterment with growth and development of fruits with wider utility (Ma, 2007).

CPPU (N-(2-chloro-4-Pyridyl)-N-Phenyl urea), a urea derived cytokinin, synthetic in nature, promotes berry growth in grape. The primary physiological effects of forchlorfenuron on grapevines cause the regulation of fruit set, berry growth and development (Humphery, 2005). It has also been shown to increase the berry size in grape by increasing its diameter, thus leading to spherical berries instead of oblong ones. Usage of CPPU alone or in combination with various PGRs at optimum concentrations and also at appropriate stage observed to stimulate various physiological and biochemical responses thereby improved the growth and productivity of crop (Sasse, 2003). The stage and time of application of bioregulators on grape vary with the region and too cultivar specific (Dokoozlian, 2003). Hence, an attempt was made to assess the impact of CPPU and application stages with certain other PGR's on bunch and berry characters of the newly introduced grape cv. Italia under Tamil Nadu conditions.

\section{Materials and Methods}

The present investigation was conducted at College Orchard, Horticultural College and Research Institute, TNAU, Coimbatore located at an altitude of $426.6 \mathrm{~m}$ above mean sea level with latitude of $9.19^{\circ} \mathrm{N}$ and longitude of $77.88^{\circ} \mathrm{E}$. The experiment was carried out during the period from February, 2014 to July, 2014. The experiment was laid in Factorial Randomized Blocks Design (FRBD) with two factors viz., 3 bioregulators (CPPU, $\mathrm{GA}_{3}$ and
Brassinosteroid) alone or in combinations and 3 stages of application (2-3 $\mathrm{mm}$ berry size stage, $7-8 \mathrm{~mm}$ berry size stage and both at 2-3 $\mathrm{mm}$ and $7-8 \mathrm{~mm}$ berry size stage). The observations on bunch circumference, bunch weight, yield per vine, berry width, peel weight, peel thickness and pedicel thickness were recorded and analyzed as per the methodology outlined by Panse and Sukhatme (1995).

\section{Results and Discussion}

The results on impact of bioregulators and application stages with bunch circumference revealed that significant differences due to bioregulators alone (Table 1). Among the bioregulators, the treatment $\mathrm{B}_{4}$ i.e., $\mathrm{GA}_{3}(10$ $\mathrm{ppm})+\mathrm{CPPU}(1 \mathrm{ppm})$ recorded the maximum 'bunch circumference' $(36.85 \mathrm{~cm})$ and the minimum 'bunch circumference' was registered in control $(32.75 \mathrm{~cm})$. This could be attributed to nourished berries and increment with bunch length and berry weight. Observations recorded on 'bunch weight' exhibited significant differences with both bioregulators and application stages including their interaction (Table 1). In contrary to the CPPU implied treatments, the treatment $\mathrm{B}_{5}$ i.e., $\mathrm{GA}_{3}(10 \mathrm{ppm})+$ Brassinosteroid $(1 \mathrm{ppm})$ registered the maximum 'bunch weight' (681.61 g) over control (542.70 g). Among the stages of application, the treatments imposed at $7-8 \mathrm{~mm}$ berry size stage recorded the maximum 'bunch weight' (652.86 g). The minimum 'bunch weight' was recorded in cumbu stage $(608.02 \mathrm{~g})$. With regard to interaction, the treatment $\mathrm{B}_{5} \mathrm{~S}_{2}$ recorded the maximum 'bunch weight' (719.94 g). Exogenous application of $\mathrm{GA}_{3}(10 \mathrm{ppm})+$ Brassinosteroid (1 $\mathrm{ppm})$ had showed promising results in increasing the bunch weight which might be attributed to certain changes in the metabolism of fruits for the improvement of sink strength followed by efficient partitioning of assimilates towards 
the developing sink in response to spray of $\mathrm{GA}_{3}(10 \mathrm{ppm})+$ Brassinosteroid (1 ppm). Similar results were observed in earlier studies by Anitha (1993), Vivency (1995) and Padashetti et al., (2010).

In a same way, observations recorded on 'yield per vine' showed significant differences with bioregulators and application stages including their interaction (Table 1). Among the bioregulators, the treatment $\mathrm{B}_{5}$ i.e., $\mathrm{GA}_{3}$ $(10 \mathrm{ppm})+$ Brassinosteroid $(1 \mathrm{ppm})$ recorded the maximum 'yield per vine' (11.02 kg/vine).

The minimum 'yield per vine' was registered by control ( $8.54 \mathrm{~kg} / \mathrm{vine})$. Among the stages of application, the treatments imposed in $7-8 \mathrm{~mm}$ berry size stage recorded the maximum 'yield per vine' (10.49 $\mathrm{kg} / \mathrm{vine})$. With regard to interaction, the treatment $\mathrm{B}_{5} \mathrm{~S}_{2}$ recorded the maximum 'yield per vine' $(12.70 \mathrm{~kg} / \mathrm{vine})$. The minimum 'yield per vine' was recorded in $\mathrm{B}_{4} \mathrm{~S}_{1}(8.10 \mathrm{~kg} / \mathrm{vine})$. The cumulative effect of physical characteristics of bunches and berries could have contributed for the increase in yield per vine and this might be due to the promotion of cell multiplication, cell expansion and differentiation and continuous mobilization of nutrients and assimilates. Similar observations were made in number of earlier studies in various crops (Tambe, 2002; Velu, 2001; Sasse, 2003; Taiz and Zeiger, 2010).

Observations recorded on 'berry width', 'peel weight' and 'peel thickness' exhibited significant differences with bioregulators and stages of application including their interaction (Table 2). The treatment $\mathrm{B}_{2} \mathrm{~S}_{2}$ recorded the maximum 'berry width' (21.18 $\mathrm{mm})$ followed by $\mathrm{B}_{3} \mathrm{~S}_{2}(21.09 \mathrm{~mm})$. The minimum 'berry width' was recorded in $\mathrm{B}_{6} \mathrm{~S}_{1}$ (17.72 mm). For observations on 'peel weight' the treatment $\mathrm{B}_{2} \mathrm{~S}_{3}$ recorded the maximum 'peel weight' $(0.63 \mathrm{~g})$, followed by $\mathrm{B}_{2} \mathrm{~S}_{2}$ and $\mathrm{B}_{4} \mathrm{~S}_{3}(0.61 \mathrm{~g})$ that all were on par with each other. The minimum 'peel weight' was recorded in control at $S_{2}$ stage $(0.39 \mathrm{~g})$. In case of 'peel thickness', the treatment $\mathrm{B}_{2} \mathrm{~S}_{3}$ recorded the maximum 'peel thickness' $(0.21$ $\mathrm{mm})$, followed by $\mathrm{B}_{4} \mathrm{~S}_{3}(0.20 \mathrm{~mm})$ that were on par with each other. The minimum 'peel thickness' was recorded in control at $\mathrm{S}_{2}$ stage $(0.11 \mathrm{~mm})$. With regard to 'pedicel thickness', the maximum 'pedicel thickness' was registered by $\mathrm{B}_{2} \mathrm{~S}_{3}(2.71 \mathrm{~mm})$ followed by $\mathrm{B}_{4} \mathrm{~S}_{3}(2.68 \mathrm{~mm})$, which were on par with each other (data not shown). The minimum 'pedicel thickness' was recorded in control at $S_{2}$ stage (1.82 mm).

Generally, the concentration and stage of application of bioregulators significantly affect berry size in grape (Halbrooks and Mortensen, 1987). In the present study, among the treatments, CPPU (1 ppm) registered the maximum 'berry width'. Similar trend was observed for peel weight and peel thickness. Usually, CPPU stimulates periclinal cell division in the berry, leading to more round or oval shaped berries compared to GA application alone (Dokoozlian, 2001).

Arima et al., (1995) reported that CPPU enhances the fruit growth in initial phase by rapid cell division and in the expansion phase by slower cell expansion. With regard to stages of application, CPPU (1 ppm) imposed at pea stage (7-8 $\mathrm{mm}$ berry size) registered the maximum berry width. This is in line with the findings of Korkutal et al., (2008), who reported the most effective stage for usage of bioregulators for enlargement of grape berries is pea berry stage.

Increased berry size in grape cv. Red Globe was noticed in treatments of $\mathrm{GA}_{3}(20 \mathrm{ppm})$ and the combination of $\mathrm{GA}_{3}(20 \mathrm{ppm})$ with CPPU (3 ppm), applied at $10 \mathrm{~mm}$ mean berry size (Quixely and Raath, 2010). Similar effect was also observed by Rizk-Alla et al., (2011) in grape cv. Black Monukka. 
Table.1 Effect of bioregulators and application stages on 'Bunch circumference (cm)', 'Bunch weight (g)' and 'Yield per vine (kg)' in grape cv. Italia

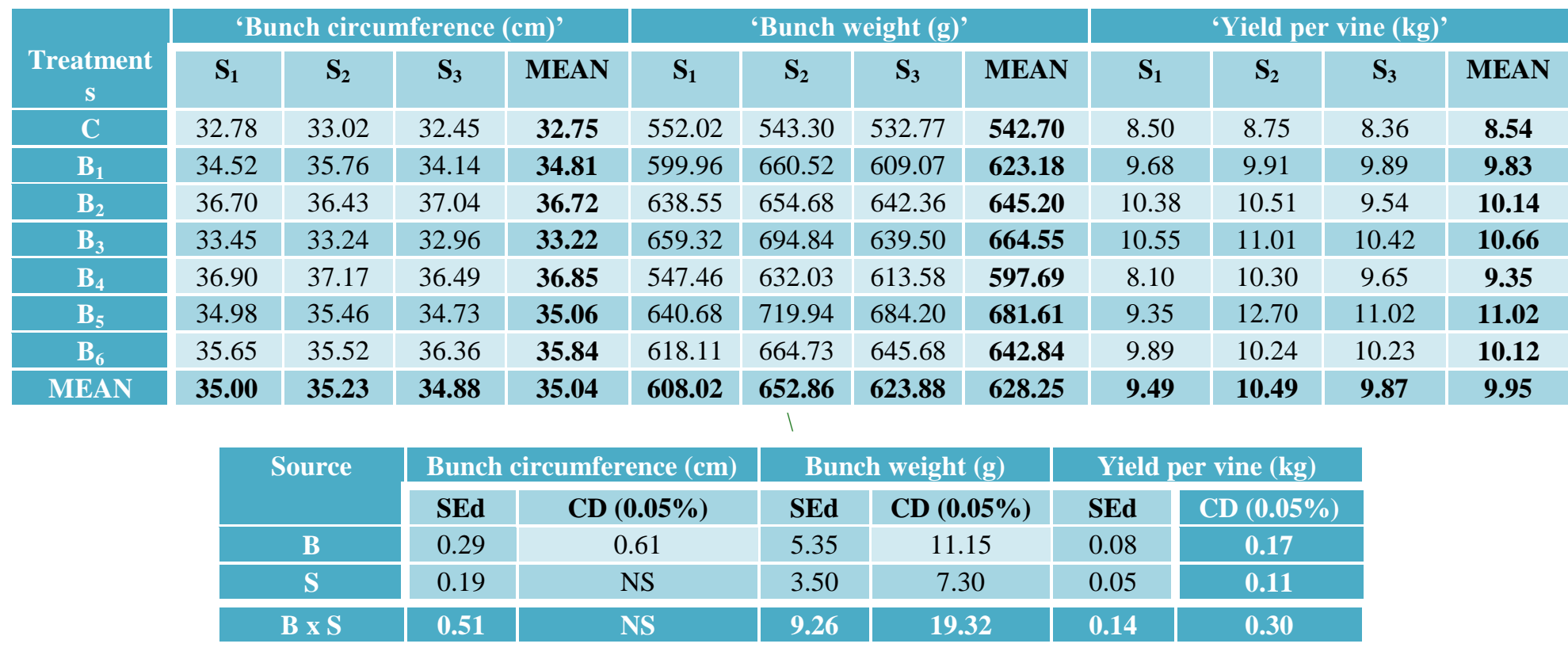

\begin{tabular}{|l|l|l|l|}
\hline $\mathbf{C}$ & Control (water spray) & $\underline{\mathbf{S}}$ & Stages of application \\
\hline$\underline{\mathbf{B}}$ & Bioregulators & $\mathbf{S}_{\mathbf{1}}$ & at 2-3 mm berry size \\
\hline $\mathbf{B}_{1}$ & $\mathrm{GA}_{3}(10 \mathrm{ppm})$ & $\mathbf{S}_{\mathbf{2}}$ & at 7-8 mm berry size \\
\hline $\mathbf{B}_{2}$ & $\mathrm{CPPU}(1 \mathrm{ppm})$ & $\mathbf{S}_{\mathbf{3}}$ & Both at 2-3 and 7-8 $\mathrm{mm}$ berry size \\
\hline $\mathbf{B}_{3}$ & Brassinosteroid $(1 \mathrm{ppm})$ & $\mathbf{N S}$ & Non-significant \\
\hline $\mathbf{B}_{4}$ & $\mathrm{GA}_{3}(10 \mathrm{ppm})+\mathrm{CPPU}(1 \mathrm{ppm})$ & & \\
\hline $\mathbf{B}_{5}$ & $\mathrm{GA}_{3}(10 \mathrm{ppm})+$ Brassinosteroid $(1 \mathrm{ppm})$ & & \\
\hline $\mathbf{B}_{6}$ & $\mathrm{GA}_{3}(10 \mathrm{ppm})+\mathrm{CPPU}(1 \mathrm{ppm})+$ Brassinosteroid $(1 \mathrm{ppm})$ & & \\
\hline
\end{tabular}

Table.2 Effect of bioregulators and application stages on 'Berry width (mm)', 'Peel weight (g)' and 'Peel thickness ( $\mathrm{mm})$ ' in grape cv. Italia

\begin{tabular}{|c|c|c|c|c|c|c|c|c|c|c|c|c|}
\hline \multirow[b]{2}{*}{ Treatments } & \multicolumn{4}{|c|}{ 'Berry width (mm)' } & \multicolumn{4}{|c|}{ 'Peel weight (g)' } & \multicolumn{4}{|c|}{ 'Peel thickness (mm)' } \\
\hline & $\mathbf{S}_{1}$ & $\mathbf{S}_{2}$ & $\mathbf{S}_{3}$ & MEAN & $\mathbf{S}_{1}$ & $\mathbf{S}_{2}$ & $\mathbf{S}_{3}$ & MEAN & $\mathbf{S}_{1}$ & $\mathbf{S}_{2}$ & $\mathbf{S}_{3}$ & MEAN \\
\hline $\mathbf{C}$ & 18.56 & 18.98 & 18.77 & 18.77 & 0.40 & 0.39 & 0.41 & 0.40 & 0.12 & 0.11 & 0.12 & 0.12 \\
\hline $\mathbf{B}_{1}$ & 17.90 & 20.21 & 19.64 & 19.25 & 0.43 & 0.55 & 0.47 & 0.48 & 0.14 & 0.16 & 0.15 & 0.15 \\
\hline $\mathbf{B}_{2}$ & 19.03 & 21.18 & 20.75 & 20.32 & 0.60 & 0.61 & 0.63 & 0.61 & 0.17 & 0.19 & 0.21 & 0.19 \\
\hline $\mathbf{B}_{3}$ & 18.46 & 21.09 & 20.39 & 19.98 & 0.53 & 0.49 & 0.56 & 0.53 & 0.16 & 0.15 & 0.18 & 0.16 \\
\hline $\mathbf{B}_{4}$ & 18.13 & 20.44 & 19.87 & 19.48 & 0.56 & 0.60 & 0.61 & 0.59 & 0.17 & 0.17 & 0.20 & 0.18 \\
\hline $\mathbf{B}_{5}$ & 20.92 & 20.34 & 19.53 & 20.26 & 0.51 & 0.48 & 0.52 & 0.50 & 0.15 & 0.15 & 0.17 & 0.16 \\
\hline $\mathbf{B}_{6}$ & 17.72 & 20.05 & 19.36 & 19.04 & 0.57 & 0.54 & 0.60 & 0.57 & 0.17 & 0.16 & 0.19 & 0.17 \\
\hline MEAN & 18.67 & 20.33 & 19.76 & 19.59 & 0.51 & 0.52 & 0.54 & 0.53 & 0.15 & 0.16 & 0.19 & 0.16 \\
\hline
\end{tabular}




\begin{tabular}{|c|c|c|c|c|c|c|}
\hline \multirow[t]{2}{*}{ Source } & \multicolumn{2}{|c|}{ 'Berry width $(\mathrm{mm}){ }^{\prime}$} & \multicolumn{2}{|c|}{ 'Peel weight (g)' } & \multicolumn{2}{|c|}{ 'Peel thickness (mm)' } \\
\hline & SEd & CD $(0.05 \%)$ & SEd & CD $(0.05 \%)$ & SEd & CD $(0.05 \%)$ \\
\hline B & 0.16 & 0.34 & 0.007 & 0.014 & 0.002 & 0.004 \\
\hline $\mathbf{S}$ & 0.11 & 0.22 & 0.004 & 0.009 & 0.001 & 0.003 \\
\hline B $\times S$ & 0.28 & 0.59 & 0.012 & 0.025 & 0.004 & 0.008 \\
\hline
\end{tabular}

\begin{tabular}{|l|l|l|l|}
\hline $\mathbf{C}$ & Control (water spray) & $\mathbf{S}$ & \multicolumn{1}{|c|}{ Stages of application } \\
\hline $\mathbf{B}$ & Bioregulators & $\mathbf{S}_{\mathbf{1}}$ & at 2-3 mm berry size \\
\hline $\mathbf{B}_{1}$ & $\mathrm{GA}_{3}(10 \mathrm{ppm})$ & $\mathbf{S}_{\mathbf{2}}$ & at 7-8 $\mathrm{mm}$ berry size \\
\hline $\mathbf{B}_{2}$ & CPPU $(1 \mathrm{ppm})$ & $\mathbf{S}_{\mathbf{3}}$ & Both at 2-3 and 7-8 $\mathrm{mm}$ berry size \\
\hline $\mathbf{B}_{3}$ & Brassinosteroid $(1 \mathrm{ppm})$ & $\mathbf{N S}$ & Non-significant \\
\hline $\mathbf{B}_{4}$ & $\mathrm{GA}_{3}(10 \mathrm{ppm})+\mathrm{CPPU}(1 \mathrm{ppm})$ & & \\
\hline $\mathbf{B}_{5}$ & $\mathrm{GA}_{3}(10 \mathrm{ppm})+$ Brassinosteroid $(1 \mathrm{ppm})$ & & \\
\hline $\mathbf{B}_{6}$ & $\mathrm{GA}_{3}(10 \mathrm{ppm})+\mathrm{CPPU}(1 \mathrm{ppm})+$ Brassinosteroid $(1 \mathrm{ppm})$ & & \\
\hline
\end{tabular}

Strong adherence of the berry to the pedicel is one of the characters required for long distance transport of any grape variety. Weaker pedicels result in separation of berries from the bunch by the breakage of pedicels. The maximum 'pedicel thickness' was recorded in the treatment bunch sprayed with CPPU (1 ppm), both at $2-3 \mathrm{~mm}$ and at $7-8$ $\mathrm{mm}$ berry size stage, while it was the minimum in control. This might be due to the increase in cell number and cell layer of the pedicel. Similar observations were also made in tulips by Arima et al., (1995). Moreover, the increase in pedicel thickness by CPPU might also be due to the increased number and density of cells in pedicel. Sharma and Jindal (1981) also reported the beneficial effects of CPPU in improving the pedicel thickness in Beauty Seedless grape, Sarig et al., (1998) in Thompson Seedless and BenArie et al., (1998) in seeded grape.

So, the present study revealed that the bioregulator treatments with CPPU (1 ppm) recorded the maximum berry width at $7-8 \mathrm{~mm}$ berry size stage. The maximum peel weight, peel thickness and pedicel thickness was registered with CPPU (1 ppm) imposed both at $2-3 \mathrm{~mm}$ and at $7-8 \mathrm{~mm}$ berry size. In case of parameters for bunch weight and yield per vine, the combined application of $\mathrm{GA}_{3}(10$ ppm) and Brassinosteroid (1 ppm) at 7-8 mm berry size expressed good response.

\section{References}

Anitha, N. 1993. Synthetic brassinosteroids and its role in few plant growth processes. Ph.D., Thesis submitted to UAS, Bangalore.

Arima, Y., K. Oshima and K. Shudo. 1995. Evaluation of a novel urea type cytokinin. Horticultural uses of for chlorfenuron. Acta Hort., 394: 75-83.

Ben-Arie, R., P. Sarig, Y. Cohen-Ahdut, Y. Zutkhi, L. Sonego, T. Kapulonov and N. Lisker. 1998. CPPU and $\mathrm{GA}_{3}$ effects on pre and postharvest quality of seedless and seeded grapes. Acta Hort., 463: 349-355.

Dokoozlian, N.K. 2001. CPPU: A Potential New Plant Growth Regulator for California Table Grapes. Grape Notes Newsletter, 1: 1-4.

Dokoozlian, N.K. 2003. Use of plant growth regulators in California table grape production. In: Proceedings of the $6^{\text {th }}$ Australian table grape technical conference, Mildura, AU. pp 33-39.

Halbrooks, M.C. and J.A. Mortensen. 1987. Influence of gibberellic acid and various management practices on berry, seed 
and cluster development in 'Orland Seedless' grape. In: Proc. Fla. State Hort. Soc., 100: 312-315.

Humphery, T. 2005. Evaluation of the new active for chlorfenuron in the product sitofex 10 EC plant growth Regulators. APUAA, Canberra, Australia. pp. 1-31.

Korkutal, I., E. Bahar and O. Gokhan. 2008. The characteristics of substances regulating growth and development of plants and the utilization of gibberellic acid $\left(\mathrm{GA}_{3}\right)$ in viticulture. World J. Agrl. Sci., 4(3): 321-325.

Ma, H.Y. 2007. Changes of endogenous hormones in grapevine during its development. Northwest Science \& Technology University of Agriculture and Forestry.

Padashetti, B.S., S.G. Angadi and S. Pattepur. 2010. Effect of pre-harvest spray of growth regulators on growth, quality and yield of seedless grape genotypes. Asian J. of Hort., 5(1): 218-221.

Panse, V.G. and P.V. Sukhatme. 1985. Statistical Methods for Agricultural Workers, ICAR. Pub. New Delhi, 115130.

Quxiley, B.W. and P.J. Raath. 2010. Utilization of gibberellic acid, CPPU and bunch applied calcium to increase Red Globe berry firmness. In: Proceedings of the $6^{\text {th }}$ table grape symposium, Visalia, California, pp 5-9.

Rizk-Alla, M.S., M.A. Abd El-Wahab and O.M. Fkry. 2011. Application of $\mathrm{GA}_{3}$ and NAA as a means for improving yield, fruit quality and storability of grape cv. Black Monukka. Nat. Sci., 9: 1-19.
Sarig, P., Y. Zuthki, N. Lisker, Y. Shkelerman and R. Ben-Arie. 1998. Natural and induced resistance of table grapes to bunch rots. Acta Hort., 464: 65-70.

Sasse, J.M. 2003. Physiological actions of brassinosteroids- An update. J. Plant Growth Regul., 22: 276-288.

Sharma, S. and P.C. Jindal. 1981. Effect of 4CPA and benzyl-adenine on berry drop, yield and quality in Beauty Seedless grape (Vitis vinifera L.). In: National Symposium on Tropical and Subtropical Fruit Crops, Bangalore (Abst.), pp. 117.

Taiz, L. and E. Zeiger. 2010. In: Plant Physiology, Sinauer Associates Inc., Publishers, Sunderland, Massachusetts, USA, 519-537.

Tambe, T.B. 2002. Effects of Gibberellic acid in combination with brassinostroid on berry size, yield and quality of Thompson Seedless grape. J. Mah. Agric. Univ., 27(2): 151-153.

Velu, V. 2001. Studies on bud load and certain crop thinning practices on vigour, yield and quality of grapes (Vitis vinifera L.) cv. Muscat. M.Sc., Thesis submitted to Tamil Nadu Agricultural University, Coimbatore.

Vivency, A.J. 1995. Influence of brassinosteroids and its combination with other growth regulator on productivity in grapes, French bean and tomato. M.Sc., Thesis submitted to UAS Bangalore.

Winkler, A.J., J.A. Cook, W.M. Kliewer and L.A. Lider. 1974. General viticulture. University of California Press, Berkeley, U.S.A.

\section{How to cite this article:}

Senthilkumar, S., R.M. Vijayakumar, K. Soorianathasundaram and Durga Devi, D. 2018. Role of CPPU and Application Stages with Other PGR's on Bunch and Berry Characters in New Grape cv. Italia under Tamil Nadu Conditions. Int.J.Curr.Microbiol.App.Sci. 7(04): 353-358. doi: https://doi.org/10.20546/ijcmas.2018.704.040 